\title{
A new subgenus of the genus Microcbelonus Szépligeti and a new species of the genus Chelonus Panzer (Hymenoptera: Braconidae) from Central Asia
}

\section{Новый подрод рода Microcbelonus Szépligeti и новый вид рода Chelonus Panzer (Hymenoptera: Braconidae) из Џентральной Азии}

\author{
V.I. Tobias \\ B.И. Тобиас
}

Zoological Institute, Russian Academy of Sciences, Universitetskaya nab., 1, St. Petersburg 199034, Russia. Зоологический институт РАН, Университетская наб., 1, Санкт-Петербург 199034, Россия.

KEY WORDS: Hymenoptera, Braconidae, Cheloninae, Microchelonus, Chelonus, new subgenus, new species, Central Asia.

КЛЮЧЕВЫЕ СЛОВА: Hymenoptera, Braconidae, Cheloninae, Microchelonus, Chelonus, новый подрод, новый вид, Центральная Азия.

ABSTRACT. A new monotypic subgenus, Rasnichelonus subgen.n. (type species Microchelonus elongatus Papp) of the genus Microchelonus Szépligeti from the south of Eastern Siberia and Mongolia, and a new species, Chelonus rasnitsynus sp.n. from Afghanistan, are described and illustrated.

РЕЗЮМЕ. Описываются как новые для науки монотипический подрод Rasnichelonus subgen.n. (с типовым видом Microchelonus elongatus Рарр) в роде Microchelonus Szépligeti с юга Восточной Сибири и Монголии и вид Chelonus rasnitsynus sp.n. из Афганистана.

\section{Introduction}

This paper is dedicated to the eminent Russian hymenopterist, Professor Alexandr P. Rasnitsyn and includes descriptions of two braconid taxa from the subfamily Cheloninae, i.e. a new subgenus, Rasnichelonus subgen.n. of the genus Microchelonus Szépligeti, 1908 from the south of Eastern Siberia and Mongolia and a new species of the genus Chelonus Panzer, 1806 from Afghanistan.

For the terminology of the morphological features, sculpture and wing venation nomenclature see Belokobylskij and Tobias [1998]. Type material of the new species is deposited in the Zoological Institute, Russian Academy of Sciences (St. Petersburg, Russia).

\section{Taxonomic part}

Genus Microchelonus Szépligeti, 1908

Microchelonus elongatus Papp, 1971 (also cited as M. rasnitsyni Tobias, 1989) has been described from
Mongolia and Zabaikalskiy Territory of Russia and was later included into the subgenus Stylochelonus Héllen, 1958 [Tobias, 2000, 2010]. The members of Stylochelonus are characterized by the following features: female antennae with more than 16 segments, abdominal apical aperture (AAA) of the male not deep, usually oval and with vertical carina, body elongate, female metasoma usually with apical tooth, head tends to expand behind eyes in above view. However, $M$. elongatus has only two diagnostic characters of Stylochelonus, viz., elongate body and head expanding behind the eyes. At the same time, this species has a number of apomorphic characters, like female antennae with 16 segments (as in the members of the subgenus Microchelonus s.str.) as well as small and round AAA with median slanting appendage. Position of male AAA above longitudinal axis of metasoma represents another valuable autapomorphy of $M$. elongatus. Three latter characters suggest that $M$. elongatus should be placed into a separate monotypic subgenus, Rasnichelonus subgen.n.

\section{Subgenus Rasnichelonus subgen.n.}

Type species Microchelonus elongatus Papp, 1971.

ETYMOLOGY. This name is a combination of the Prof. A.P. Rasnitsyn's surname and a chelonine generic name, Chelonus Panzer. Gender is masculine.

DIAGNOSIS. Body elongate; mesosoma twice longer its height; metasoma 2.3-2.5 times longer its width (Figs 5, 8). Head behind eyes widened in dorsal view (Figs 1, 3). Female antenna 16-segmented, as long as head and mesosoma combined. Female carapace apically not incurved below (Fig. 8), without apical tooth and long basal carinae. Male AAA of carapace (Figs 6, 

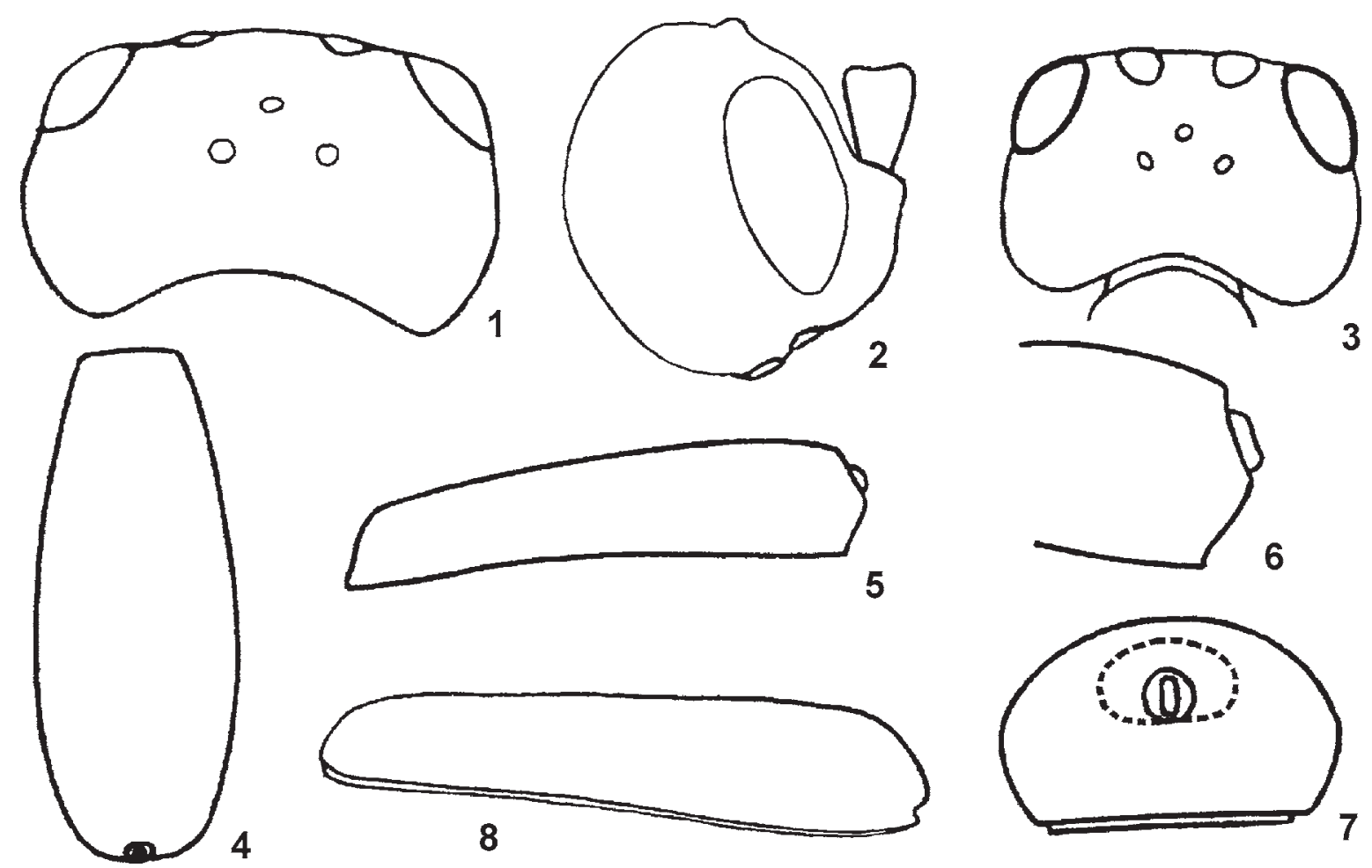

Figs 1-8. Microchelonus (Rasnichelonus subgen.n.) elongatus Papp (1-3, 8 - female; 4-7 - male). 1, 3 - head, dorsal view; 2 head, lateral view; 4 - metasoma, dorsal view; 5, 8 - metasoma, lateral view; 6 - apex of metasoma, lateral view; 7 - apex of metasoma, posterior view.

Рис. 1-8. Microchelonus (Rasnichelonus subgen.n.) elongatus Pарр (1-3, 8- самка; 4-7 - самец). 1, 3 - голова, вид сверху; 2 — голова, вид сбоку; 4 - метасома, вид сверху; 5, 8 - метасома, вид сбоку; 6 - вершина метасомы, вид сбоку; 7 - вершина метасомы, вид сзади.

7) situated above longitudinal axis of metasoma, small, circular, with median slanting appendage.

CONTENT. The only species of this subgenus, $M$. elongatus Papp (= M. rasnitsyni Tobias), is known [Papp, 1971; Tobias, 1989, 2010].

\section{Key to subgenera of Microchelonus SzÉPligeti}

1. Female antennae more than 16 -segmented ... 2

- Female antennae 16-segmented.....

2. Head behind eyes strongly widened, upper part of temp with coarse and concentric creases. Body strongly elongate, mesosoma 2.5 times longer than high, metasoma 3.0 times longer than wide. - Antennae with about 30 segments. Male AAA deep and elongate, fusiform. (Monotypic; South China)....

Scabrochelonus He, Chen et Achterberg

- Head behind eyes not or weakly widened, upper part of temple without coarse and concentric creases. Body not strongly elongated, mesosoma not more than twice longer than high, metasoma not more than 2.5 times longer than wide.

3. Mesosoma robust, not more than 1.5 times longer than high. Female metasoma without apical tooth. Male metasoma with deep AAA and without vertical carinae. Female antennae usually about 30 -segmented. (7 species; Palaearctic)....
- Mesosoma elongate, usually 1.5-2.0 times longer than high. Female metasoma usually with apical tooth. Male metasoma with shallow AAA and with vertical carina. Female antennae with 18-25 segments. (10 species; Palaearctic) Stylochelonus Héllen

4. Frons with deep excavation and with lateral carinae. Metasoma with a pair of long basal carinae. (Monotypic; Russian Far East) .... Carinichelonus Tobias

- Frons without or with shallow excavation, without lateral carinae. Metasoma without a pair of long basal carinae

5. Body elongate, mesosoma twice longer than high, metasoma 2.3-2.5 times longer than wide (Figs 5, 8). Head behind eyes distinctly widened in dorsal view (Figs 1, 3 ). Male AAA (Figs 6, 7) shallow, situated above longitudinal axis of metasoma, small, circular, with middle slanting appendage. [Monotypic; Russia (south of Eastern Siberia), Mongolia] ......... Rasnichelonus subgen.n.

- Body less elongate, mesosoma less than twice longer than high, metasoma usually not more than 2.0 times longer than wide. Head behind eyes usually roundly narrowed in dorsal view. Male AAA deep, situated medially or ventrally to longitudinal axis of metasoma, often of medium size or large, transverse, with more or less slender appendage; male metasoma rarely without AAA. (More than 400 species; Palaearctic)

Microchelonus Szépligeti 

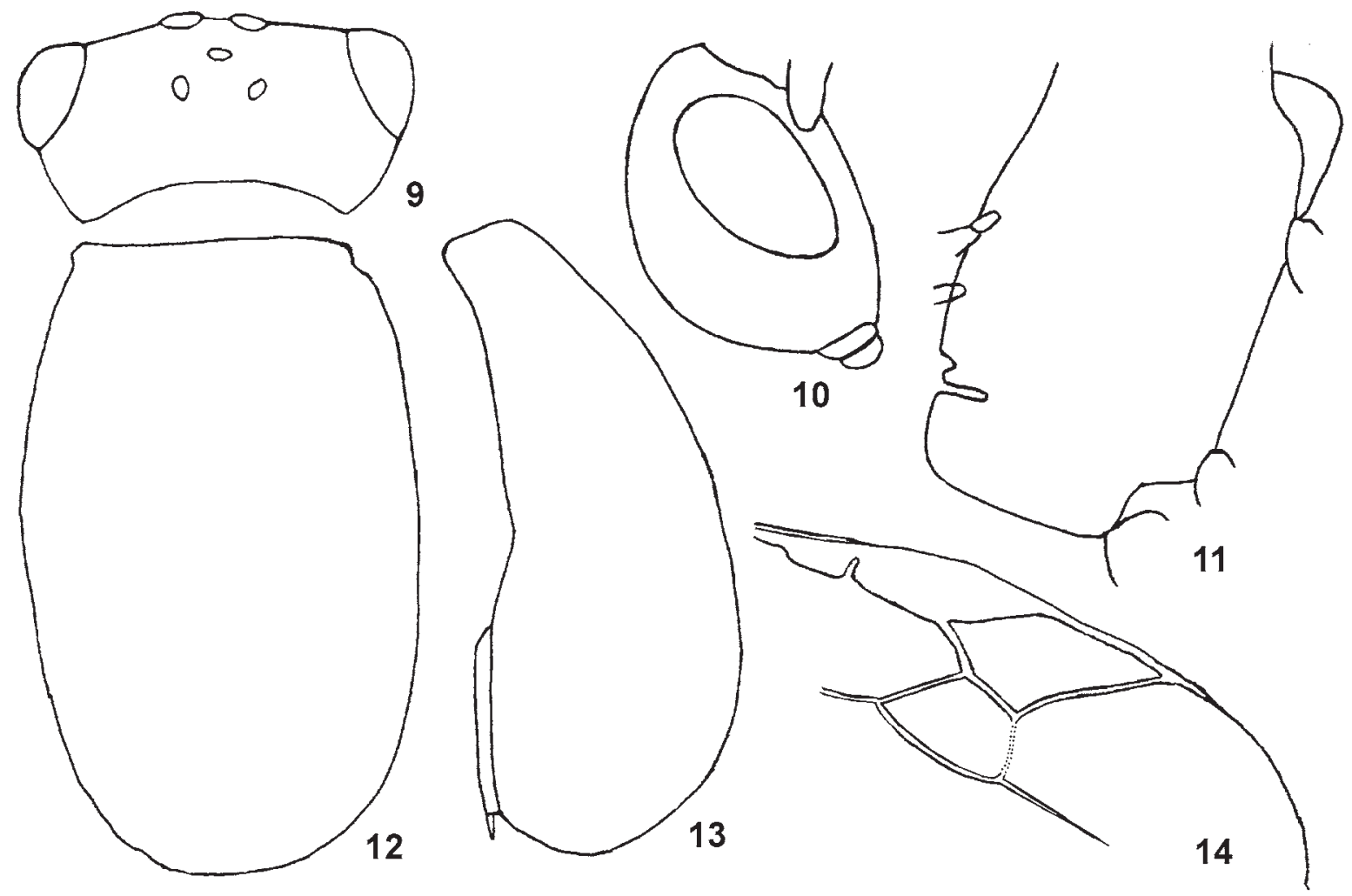

Figs 9-14. Chelonus rasnitsynus sp.n., female. 9 - head, dorsal view; 10 - head, lateral view; 11 - mesosoma, lateral view; 12 metasoma, dorsal view; 13 - metasoma, lateral view; 14 - part of fore wing.

Рис. 9-14. Chelonus rasnitsynus sp.n., самка. 9 - голова, вид сверху; 10 - голова, вид сбоку; 11 - мезосома, вид сбоку; 12 метасома, вид сверху; 13 - метасома, вид сбоку; 14 - часть переднего крыла.

\section{Genus Chelonus Panzer, 1806}

Body of the members of this genus is usually more or less roughly sculptured, mainly black, but carapace often with pale basal spots. Female antennae always more than 16-segmented. Male metasoma always without AAA. More than 120 Chelonus species are known in the Palaearctic fauna.

\section{Chelonus rasnitsynus sp.n.}

Figs 9-14.

DESCRIPTION. Female. Body length 4.0-5.5 mm. Head oval in front view, 1.3 times as wide as high, roundly narrowed behind eyes in dorsal view, 1.8 times as wide as long and 1.1 times as wide as mesonotum. Transverse diameter of eye 0.7 times length of temple in dorsal view. Width of ocellar triangle shorter than OOL; POL twice as long as ocellar diameter. Longitudinal diameter of eye 1.5 times its transverse diameter, 1.5 times length of malar space. Face 2.5 times as wide as high. Labio-maxillary complex weakly protruding. Maxillary palpus as long as height of face and clypeus combined. Antenna becomes more slender towards apex, with 24 segments, somewhat longer than head and mesosoma combined; third antennal segment 2.5 times longer, fifth segment 1.5 times longer and eleventh segment 1.3 times longer their respective width; 5-6 subapical segments as long as wide; 22 nd and 23rd antennal segments somewhat longer their width; apical segment oval, 1.5 times longer than wide. Mesosoma 1.8 times longer than high. Propodeum with fine transverse carina, without lateral tubercles. Pterostigma of forewing as long as metacarp. Third abscissa of radial vein of forewing 3.0 times longer than second abscissa; second abscissa of radial vein as long as first abscissa, 1.5 times longer than first radiomedial vein. Hind femur 3.2 times longer than wide. Hind tibia 1.1 times longer than hind tarsus. Inner spur of hind tibia almost half as long as hind basitarsus. Apical segment of hind tarsus as long as its third segment. Carapace of metasoma oval, incurved apically and below along 0.05 its length, 1.4 times longer than wide, 2.5 times longer than high. Ovipositor short.

Sculpture. Head behind eye and face with coarse and short transverse wrinkles; large part of temple smooth and shining. Mesonotum with coarse and irregular wrinkles, mesopleuron regularly areolate, with wrinkles. Carapace finely areolate, with sparse longitudinal wrinkles on basal half of metasoma.

Colour. Body reddish brown, upper part of head, antennae, and sometimes frons black, temples usually 
reddish brown or reddish yellow. Fore and middle coxae and all trochanters black; all femora dark brown, with yellowish brown apices; fore and middle tibiae yellowish brown, hind tibia dark brown, brownish yellow in apical part; all tarsi dark brown. Wings faintly infuscate; pterostigma black.

Male. Body length $5.5 \mathrm{~mm}$. Width of ocellar triangle equal to OOL; POL 4.0 times ocellar diameter. Longitudinal diameter of eye 1.8 times malar space. Antennae setiform, with 27 segments, as long as head, mesosoma and half of metasoma combined. Metasoma 1.65 times longer its width, twice longer its height, with fine areolate sculpture and longitudinal wrinkles on its whole surface. Body black, metasoma dark brown; legs darker, all femora black. Otherwise similar to female.

TYPE MATERIAL. Holotype: + , Afghanistan, $10 \mathrm{~km} \mathrm{~W}$ Baghlan, semi-savanna, 16.VI.1966 (E.S. Sugonjaev). Paratypes: 2 ㅇ, $1 \mathrm{O}^{3}$, with same labels as holotype.

DIAGNOSIS. Chelonus rasnitsynus sp.n. is closely related to $C h$. oculator Fabricius, 1775 that is widely distributed in Europe, North Africa, the Caucasus, Kasakhstan, Middle Asia, Iran, and Afghanistan [Tobias, 1976, 1986; Yu et al., 2005], but differs from it in having longer and more or less regularly areolate mesosoma (irregularly and coarsely wrinkled in $\mathrm{Ch}$. oculator), distinct dorsal chink between mesothorax and propodeum, smooth lower part of temples, reddish brown female body with darkened legs (female body usually black, with yellow legs and basal abdominal spots in Ch. oculator).
DISTRIBUTION. Afghanistan.

\section{ACKNOWLEDGEMENT}

The present work was partly supported by the grant No. 10-04-00265 from the Russian Foundation for Basic Research.

\section{References}

Belokobylskij S.A., Tobias V.I. 1998. [Family Braconidae. Introduction] // Lehr P.A. (ed.). Key to insects of the Russian Far East. Neuropteroidea, Mecoptera, Hymenoptera. Vladivostok: Dal'nauka. Vol.4. No.3. P.8-26 [in Russian].

Papp J. 1971. Results of the zoological expeditions of Dr. Z. Kaszab in Mongolia. Hymenoptera: Braconidae. II // Acta Zoologica Hungarica. Vol.17. No.1-2. P.51-90.

Tobias V.I. 1976. [Braconidae (Hymenoptera) of the Caucasus]. Leningrad: Nauka. 287 pp. [in Russian].

Tobias V.I. 1986. [Subfam. Cheloninae] // Medvedev G.S. (ed.). Key to insects of the European part of the USSR. Hymenoptera. Vol.3. No.4. P.293-335 [in Russian].

Tobias V.I. 1989. [Braconids of the genus Microchelonus (Hymenoptera, Braconidae) of Mongolia] // Insects of Mongolia. Vol.10. P.413-505 [in Russian].

Tobias V.I. 2000. [Subfam. Cheloninae] // Lelej A.S. (ed.). Key to insects of the Russian Far East. Neuropteroidea, Mecoptera, Hymenoptera. Vladivostok: Dal'nauka. Vol.4. No.4. P.426571 [in Russian].

Tobias V.I. 2010. [Palaearctic species of the genus Microchelonus Szépligeti (Hymenoptera, Braconidae, Cheloninae): key to species] // Proceedings of the Russian Entomological Society. Vol.81. No.1. P.1-354 [in Russian].

Yu D. S., van Achterberg C., Horstmann K. 2005. World Ichneumonoidea 2004. Taxonomy, Biology, Morphology and Distribution. CD/DVD. Vancouver: Taxapad. http://www.taxapad. com 